\title{
COVER CROPS AND STRAW MANAGEMENT ON YIELD COMPONENTS OF CRAMBE
}

\author{
CULTURAS DE COBERTURA E MANEJO DA PALHADA SOBRE OS \\ COMPONENTES DE PRODUÇÃO DE CRAMBE
}

\author{
Doglas BASSEGIO ${ }^{1}$; Reginaldo Ferreira SANTOS ${ }^{2}$; Deonir SECCO² Ivan WERNCKE $^{2}$; \\ Marcos Vinícius Mansano SARTO ${ }^{1}$ \\ 1. São Paulo State University - UNESP, Department of Crop Science, Botucatu, São Paulo, Brazil. doglasbassegio@gmail.com; 2. \\ Western Paraná State University - UNIOESTE, Department of Energy in Agriculture, Cascavel, Paraná, Brazil.
}

\begin{abstract}
The objective of this study was to evaluate the dry matter (DM) yield and nutrient accumulation in cover crops and the effect of these, as well as mechanical management of crop residues on growth and grain yield of crambe (Crambe abyssinica). The experiment was conducted in Santa Helena, Paraná, Brazil in Rhodic Hapludox (Red Latosol in the Brazilian classification) in experimental design of randomized complete blocks with four replications in a split-plot. The plots were: Pearl millet (Pennisetum glaucum), grass brachiaria (Brachiaria brizantha), forage sorghum (Sorghum bicolor) and sunn hemp (Crotalaria juncea) and an area fallow (spontaneous weed) and the sub-plots, the mechanical or not management of crop residues on the soil surface (Triton ${ }^{\circledR}$ ). Grass brachiaria produced less amount of DM and showed less accumulation of nutrients. Other cover crops did not differ in DM production, but the sunn hemp showed the highest concentrations of $\mathrm{N}$ and $\mathrm{Ca}$, while pearl millet $\mathrm{P}$. The mechanical management of crop residues on the soil surface not influence the yield components of crambe, however provides higher final plant density. The crambe grown after sunn hemp showed higher DM accumulation $\left(1,826 \mathrm{~kg} \mathrm{ha}^{-1}\right)$ and grain yield $\left(1,066 \mathrm{~kg} \mathrm{ha}^{-1}\right)$.
\end{abstract}

KEYWORDS: Crambe abyssinica. Cover crops. Straw management. Nutrient cycling.

\section{INTRODUCTION}

Nowadays, there is great demand for oilseed species for use as a feedstock for biodiesel, mainly producing species of grains that are not used as a food source, so that does not compete with the food sector focused crops. In this sense, the crambe (Crambe abyssinica Hochst. Former. RE Fries) emerges as second crop culture focused on commercial framework for oil production, and come in entering farming systems due to ease of cultivation, low cost of deployment, good productivity grain yield (1000-1500 $\left.\mathrm{kg} \mathrm{ha}^{-1}\right)$ and oil (26-38\%) (PITOL, 2010).

For the crambe develops perfectly in tropical soils starting from no-till, the maintenance of vegetation cover on the soil is essential as well as the rotation with antecedent species that contribute to the nutritional supplementation of culture. In this context, the use of cover crops search systems enable agricultural production using crop residues for subsequent species. Therefore, it is necessary to introduce alternative plants with the potential of producing high amounts of MS, so that the soil remains covered by longer (CRUSCIOL et al., 2012).

Accordingly, another aspect that should be evaluated is the management of cover crops before the sowing of the subsequent crop, since it influences the decomposition and, consequently, the release of nutrients to the crop in succession. However, often the use of implements such as horizontal crusher straw can lead to disadvantages, low operational efficiency, high cost and risk of soil compaction (DENARDIN; KOCHHANN, 1993). However, according to Furlani Junior et al. (2013), under certain conditions it is necessary for the proper establishment and growth of the subsequent crop management of crop residues.

The adoption of conservation cropping systems such as no-till has been presented as a viable alternative to assure the sustainability of soil agricultural use. However, the success of this production system depends, among other factors, on the input and maintenance of large amounts of straw on the soil surface. There is evidence that in no-till cultivated with only cash-crop has resulted in soil degradation (TAVARES FILHO et al., 2010) by favoring increase soil bulk density and penetration resistance, and reduced total porosity (TAVARES FILHO et al., 2001). On the other hand, important benefits have been observed in soil structure, both in the short and long term, when cover crops with vigorous root systems and high capacity to produce dry matter are used (COSTA et al., 2011; FERRARI NETO et al., 2011; NASCENTE; CRUSCIOL et al., 2012).

In addition to crop rotation, the mechanical management of crop residues on the soil surface, such as the horizontal straw crusher, can change the 
nutrient dynamics in the soil profile under no till and affect crop yields. Silva et al. (2010) and Ferrari Neto et al. (2011) found that the castor bean yield was higher in the absence of mechanical management of crop residues. However, Crusciol and Soratto (2007) found no effect of mechanical management of crop residues on the nutrition and yield of peanut crop under no till.

Therefore, due to the scarcity of information on the subject, this work aimed to evaluate the DM production and nutrient accumulation in cover crops and the effect of mechanical management of crop residues on growth and grain yield of crambe.

\section{MATERIAL AND METHODS}

The experiment was carried out in Santa Helena, Paraná State, Brazil (245' S, 54¹8' W, altitude of $282 \mathrm{~m}$ ). The soil was a Rhodic Hapludox (Red Latosol in the Brazilian classification), with 700,150 , and $150 \mathrm{~g} \mathrm{~kg}^{-1}$ of clay, silt and sand, respectively. The regional climate is relatively warm and wet. The 30-year mean annual temperature is $22.1{ }^{\circ} \mathrm{C}$ with a July minimum of $16.8{ }^{\circ} \mathrm{C}$ and a January maximum of $27.6{ }^{\circ} \mathrm{C}$, and mean annual precipitation of $1,800 \mathrm{~mm}$. Rainfall and maximum and minimum temperatures recorded during the experiment are shown in Figure 1.

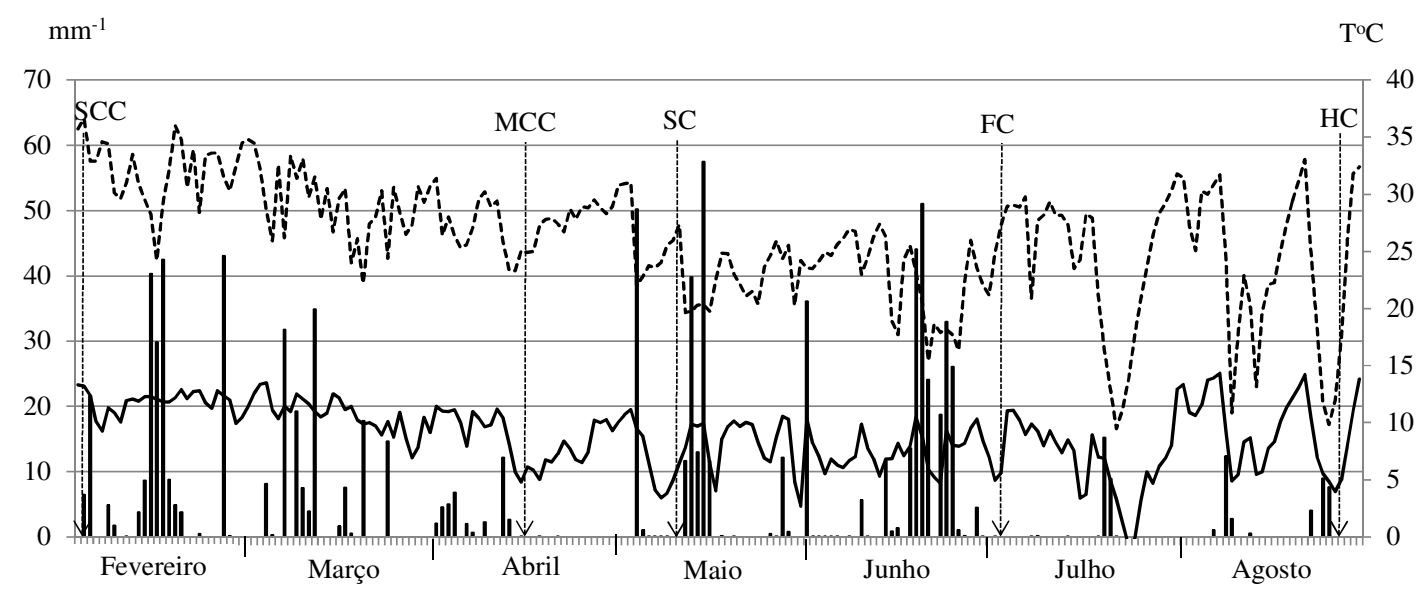

Figure 1. Maximum temperatures (---) and minimum (-) and rainfall ( $\mid$ ) during the experiment. Seeding of cover crops (SCC); mechanical management of cover crops (MCC); sowing of crambe (SC); flowering of crambe (FC); harvest of crambe (HC).

Source: Meteorological Station of the Agronomic Institute of Paraná - IAPAR.

The experimental area had been under notill for seven years, cropped to soybean/corn in succession. Before starting the experiment, soil samples were taken from the surface layer $(0-0.20$ $\mathrm{m})$, air dried, sieved through a $2 \mathrm{~mm}$ mesh, and analyzed as in Embrapa (2009). Soil chemical analysis showed $\mathrm{pH}$ in $\mathrm{CaCl}_{2} 0.01 \mathrm{M}$ of $5.1,14 \mathrm{~g}$ $\mathrm{dm}^{-3}$ of organic carbon, $21 \mathrm{mg} \mathrm{dm}{ }^{-3}$ of $\mathrm{P}$ (Mehlich1), $0.13 \mathrm{cmol}_{\mathrm{c}} \mathrm{dm}^{-3}$ of $\mathrm{K}, 6.07 \mathrm{cmol}_{\mathrm{c}} \mathrm{dm}^{-3}$ of $\mathrm{Ca}$, $2.50 \mathrm{cmol}_{\mathrm{c}} \mathrm{dm}^{-3}$ of $\mathrm{Mg}, 12.98 \mathrm{cmol}_{\mathrm{c}} \mathrm{dm}^{-3}$ of CEC, and $67 \%$ of soil base saturation.

The experiment was set up in a randomized complete blocks in a split-plot design with four replications. Pearl millet [Pennisetum glaucum (L.) R. Brown], grass brachiaria [Brachiaria brizantha (Hochst) Stapf var. Marandu], forage sorghum [Sorghum bicolor (L.) Moench], sunn hemp [Crotalaria juncea L.], and an additional treatment in fallow (spontaneous weed) were grown on the whole plots. Sub-plots consisted of mechanical or not management of crop residues on the soil surface.
A total of 40 sub-plots, $3.2 \mathrm{~m}$ wide $\times 6.0 \mathrm{~m}$ long, comprised the entire study area.

The four experimental crop rotations and fallow were initially established on February 01, 2013. The sowing of cover crops was performed in $0.45 \mathrm{~m}$ spaced rows at densities of $20,40,15$, and $20 \mathrm{~kg}$ seeds $\mathrm{ha}^{-1}$ of pearl millet, grass brachiaria, forage sorghum and sunn hemp, respectively (MURAISHI et al., 2005; SIMIDU et al., 2010). Fertilization of cover crops was carried out by applying $100 \mathrm{~kg} \mathrm{ha}^{-1} 10-15-15$ formulation at sowing. These crops remained in the area until desiccation on April 22, 2013 with glyphosate (1.44 $\mathrm{kg} \mathrm{ha}^{-1}$ a.i.) at a spray volume of $200 \mathrm{~L} \mathrm{ha}^{-1}$.

Seven days after the management of cover crops and spontaneous weed, in half of each experimental plot, crop residues were crushed in particles approximately 50 to $70 \mathrm{~mm}$ long using a mechanical crusher of crop residues $\left(\operatorname{Tritton}^{\odot}\right)$. In another sub-plot, crop residues were manually cut close to soil and accommodated on the soil surface. 
Crambe (Crambe abyssinica Hochst, cv. FMS-Brilhante) was planted on May 10, 2013, in rows spaced $0.45 \mathrm{~m}$ with a density of 20 seeds $\mathrm{m}^{-1}$, fertilized with 10,30 and $30 \mathrm{~kg} \mathrm{ha}^{-1}$ of $\mathrm{N}, \mathrm{P}_{2} \mathrm{O}_{5}$ and $\mathrm{K}_{2} \mathrm{O}$, respectively, applied in the seed furrows, as recommended by Pitol (2010).

In April 2013, immediately before of management of cover crops and spontaneous weed, pearl millet, grass brachiaria, forage sorghum and sunn hemp were sampled, from three random points per plot, using a $0.50 \times 0.50 \mathrm{~m}$ wooden frames. The collected plant material was then oven-dried at 65 ${ }^{\circ} \mathrm{C}$ for five days to determine dry matter yield.

The concentrations of macronutrients $(\mathrm{N}, \mathrm{P}$, $\mathrm{K}, \mathrm{Ca}$ and $\mathrm{Mg}$ ) were determined according Malavolta et al. (1997) and carbon (C) by the method of Walkley and Black, as described by Tedesco et al. (1995). With the results, the concentrations of macronutrients and $\mathrm{C}$, were calculated $\mathrm{C} / \mathrm{N}$ ratio.

The production of DM of the crambe was assessed at flowering, corresponding to $50 \mathrm{DAE}$, through the collection of two samples in each subplot with a frame of $0.50 \times 0.50 \mathrm{~m}$ and drying in a forced ventilation temperature of $65{ }^{\circ} \mathrm{C}$ for five days and determine dry matter production (DM, $\mathrm{kg}$ $\left.\mathrm{ha}^{-1}\right)$.

The final plant density (plant ha ${ }^{-1}$ ) and grain yield $\left(\mathrm{kg} \mathrm{ha}^{-1}\right)$ of crambe was determined in an area of $4.5 \mathrm{~m}^{2}$ within each sub-plot, becoming the two central lines. The component yield, thousand grain weight (TGW) was determined on ten plants selected at random in each sub-plot. Grain yield and grain weight were expressed corrected to $130 \mathrm{~g} \mathrm{~kg}^{-1}$ of moisture.

Original data were submitted to ANOVA and the results of different crop rotations and management of crop residues were compared using the Tukey test $(\mathrm{p} \leq 0.05)$ and $\mathrm{F}$ test $(\mathrm{p} \leq 0.05)$, respectively. All analyses were performed using Sisvar 5.0 software for Windows (Statistical Analysis Software, UFLA, Lavras, MG, BRA).

\section{RESULTS AND DISCUSSION}

\section{Dry matter production and nutrient accumulation of cover crops}

Dry matter production of forage sorghum, pearl millet and sunn hemp was higher than for grass brachiaria (Table 1). This occurred because the grass brachiaria, unlike of other crops, be a perennial forage species, and at 80 days after emergence the crop was not at the stage of maximum DM accumulation (early flowering), as reported by Pacheco et al. (2011) for species of the genus Brachiaria sp. Similar dry matter production of pearl millet is reported in the literature. Silva et al. (2010) and Crusciol and Soratto (2007) found DM yield of pearl millet after 71 and 75 days after emergence of 14,040 and $8,909 \mathrm{~kg} \mathrm{ha}^{-1} \mathrm{DM}$, respectively. For sunn hemp, Barbosa et al. (2011) and Silva et al. (2010) with management at 80 days after emergence have obtained lower DM production, respectively of 2,069 and $8,111 \mathrm{~kg} \mathrm{ha}^{-1}$. The DM yield of forage sorghum observed by Barbosa et al. (2011), Carvalho et al. (2011), and Ferreira et al. (2011) were lower than this study, respectively of $6,435,6,630$ and $9,560 \mathrm{~kg} \mathrm{ha}^{-1}$. This high DM production of cover crops, especially for forage sorghum, pearl millet and sunn hemp, it becomes extremely important for improving soil properties under no-till, mainly by reduce soil bulk density and penetration resistance, increase total soil porosity (CALONEGO; ROSOLEM, 2010), and improve the structure of soil aggregates (CALONEGO; ROSOLEM, 2008). In the fallow treatment was not found significant spontaneous weed on the soil surface at 80 days after the experiment installation, due to the chemical control of weeds in the seeding of cover crops. Barbosa et al. (2011) also found no presence of spontaneous weed in fallow area; the authors attributed this fact to desiccant herbicide application before installation of crops.

Table 1. Dry matter production (DM), macronutrients concentrations and $\mathrm{C} / \mathrm{N}$ ratio of cover crop residues at the time of plants desiccation

\begin{tabular}{lccccccc}
\hline Cover crops & $\begin{array}{c}\mathrm{DM} \\
\left(\mathrm{kg} \mathrm{ha}^{-1}\right)\end{array}$ & $\mathrm{N}$ & $\mathrm{P}$ & $\mathrm{K}$ & $\mathrm{Ca}$ & $\mathrm{Mg}$ & \multirow{2}{*}{$\begin{array}{c}\mathrm{C} / \mathrm{N} \\
\text { ratio }\end{array}$} \\
\cline { 3 - 7 } & $11,769 \mathrm{a}$ & $14.8 \mathrm{~b}$ & $3.5 \mathrm{bc}$ & $12.8 \mathrm{~b}$ & $6.4 \mathrm{c}$ & $6.3 \mathrm{a}$ & $39.6 \mathrm{ab}$ \\
Sorghum & $11,191 \mathrm{a}$ & $12.2 \mathrm{bc}$ & $5.3 \mathrm{a}$ & $15.6 \mathrm{a}$ & $15.8 \mathrm{~b}$ & $6.8 \mathrm{a}$ & $44.7 \mathrm{ab}$ \\
Pearl millet & $10,269 \mathrm{a}$ & $28.7 \mathrm{a}$ & $2.8 \mathrm{c}$ & $7.4 \mathrm{c}$ & $21.0 \mathrm{a}$ & $6.5 \mathrm{a}$ & $33.5 \mathrm{~b}$ \\
Sunn hemp & $5,532 \mathrm{~b}$ & $9.8 \mathrm{c}$ & $4.5 \mathrm{ab}$ & $16.7 \mathrm{a}$ & $5.1 \mathrm{c}$ & $6.7 \mathrm{a}$ & $52.8 \mathrm{a}$ \\
Brachiaria & - & - & - & - & - & - & - \\
Fallow & 9.4 & 10.0 & 10.8 & 7.5 & 14.4 & 3.2 & 12.5 \\
\hline \multicolumn{1}{c}{$\mathrm{CV}(\%)$} & & &
\end{tabular}

Values represented by the different letters, in each column show significant differences (Tukey test, $\mathrm{P} \leq 0.05$ ). 
Sunn hemp showed the highest concentrations of $\mathrm{N}$ and $\mathrm{Ca}$ and lower concentrations of $\mathrm{P}$ and $\mathrm{K}$ in DM (Table 1). The $\mathrm{Mg}$ concentration did not vary between cover crops. Pearl millet had the highest concentration of $\mathrm{P}$ and $\mathrm{K}$ in dry matter compared to forage sorghum and sunn hemp (Table 1). Silva et al. (2010) found higher concentrations of $\mathrm{K}\left(22.9 \mathrm{~g} \mathrm{~kg}^{-1}\right)$ and $\mathrm{Mg}$ $\left(3.4 \mathrm{~g} \mathrm{~kg}^{-1}\right)$ in the DM of pearl millet in comparison to the sunn hemp. Forage sorghum and pearl millet only absorb $\mathrm{N}$ from the soil, while the sunn hemp obtains part of the $\mathrm{N}$ by the biological nitrogen fixation process, evidencing the importance of legumes to the sustainability of the production system (FERREIRA et al., 2011).

The $\mathrm{C} / \mathrm{N}$ ratio of grass brachiaria was higher than the sunn hemp, but not differs from forage sorghum and pearl millet (Table 1). Silva et al. (2010) also observed lower $\mathrm{C} / \mathrm{N}$ ratio for sunn hemp (35.4), compared to millet (42.4) and sunn hemp + pearl millet (42.1). The $\mathrm{C} / \mathrm{N}$ ratio of sunn hemp and pearl millet, on average, on average is situated in around 13:1 and 30:1 (PERIN et al., 2006).
The amount of $\mathrm{N}$ accumulated in the cover crop residues on soil surface at the time of ranging from 55 to $295 \mathrm{~kg} \mathrm{ha}^{-1}$ for grass brachiaria and sunn hemp, respectively (Table 2). The amount of $\mathrm{P}$ accumulated in the cover crop residues ranging from 25 to $59 \mathrm{~kg} \mathrm{ha}^{-1}$ for grass brachiaria and pearl millet, respectively. The amount of $\mathrm{K}$ accumulated in crop residues ranging from 76 and $174 \mathrm{~kg} \mathrm{ha}^{-1}$ for sunn hemp and pearl millet, respectively. The amount of $\mathrm{Ca}$ accumulated in crop residues ranging from 29 and $214 \mathrm{~kg} \mathrm{ha}^{-1}$ for grass brachiaria and sunn hemp, respectively. The amount of $\mathrm{Mg}$ accumulated in crop residues ranging from 37 and $76 \mathrm{~kg} \mathrm{ha}^{-1}$ for grass brachiaria and pearl millet, respectively. The high capacity of sorghum forage, sunn hemp and pearl millet to extract soil nutrients, especially $\mathrm{N}$ and $\mathrm{K}$, reflects the important role cover crops play in nutrient cycling in soils under crop rotation systems, providing less loss of nutrients in the soilplant system, defining an absorption cycle and other soil nutrient return that may be used by subsequent crops.

Table 2. Amount of macronutrients accumulated (in $\mathrm{kg} \mathrm{ha}^{-1}$ ) in cover crops

\begin{tabular}{lccccc}
\hline Cover crops & $\mathrm{N}$ & $\mathrm{P}$ & $\mathrm{K}$ & $\mathrm{Ca}$ & $\mathrm{Mg}$ \\
\hline Sorghum & $176 \mathrm{~b}$ & $40 \mathrm{~b}$ & $150 \mathrm{a}$ & $76 \mathrm{c}$ & $74 \mathrm{a}$ \\
Pearl millet & $136 \mathrm{bc}$ & $59 \mathrm{a}$ & $174 \mathrm{a}$ & $176 \mathrm{~b}$ & $76 \mathrm{a}$ \\
Sunn hemp & $295 \mathrm{a}$ & $29 \mathrm{~b}$ & $76 \mathrm{~b}$ & $214 \mathrm{a}$ & $67 \mathrm{a}$ \\
Brachiaria & $55 \mathrm{c}$ & $25 \mathrm{~b}$ & $92 \mathrm{~b}$ & $29 \mathrm{~d}$ & $37 \mathrm{~b}$ \\
Fallow & - & - & - & - & - \\
\hline CV $(\%)$ & 19.0 & 14.3 & 11.2 & 9.2 & 8.9 \\
\hline
\end{tabular}

Values represented by the different letters, in each column show significant differences (Tukey test, $\mathrm{P} \leq 0.05$ ).

\section{Yield components and grain yield of crambe}

Yield components and grains yield of crambe were affected by the occurrence of frost in the flowering stage of the crop. Crambe is a coolseason annual crop but does not possess a high level of frost resistance (PITOL, 2010).

The SDM of the crambe was higher when grown in rotation with sunn hemp (Table 3 ). The SDM yield of crambe in rotation the others cover crop was similar. Sunn hemp is efficient in fix atmospheric N (FERREIRA et al., 2011), responsible by the initial plant growth and DM accumulation. In addition, of crop residues of sunn hemp has low $\mathrm{C} / \mathrm{N}$ ratio, which favors rapid decomposition and release of this nutrient for subsequent culture (CERETTA et al., 1994). There was no effect of management of crop residues in DM yield of crambe (Table 3). This may be due to the rapid release of $\mathrm{N}$ by crop residues from sunn hemp, even without mechanical management of crop residues on the soil surface. Thus, when the system of crop rotation provide high amount of dry matter on the soil surface, appropriate attention should be given to chemical management these species, as well as use sowing machine with efficient straw cutting system and seed deposition, or use of mechanical management of crop residues.

The final plant density was higher in rotation with sunn hemp and fallow area (Table 3), due to less interference of crop residues in the court system and seed deposition at the time of sowing. Mechanical management of crop residues on the soil surface also provided higher final plant density. According to Muraishi et al. (2005) the best distribution of crop residues on the soil surface provides less resistance to penetration and displacement of cutting systems of the sower. Silva et al. (2010) found higher densities of castor bean plants in rotation with millet single and intercropped with sunn hemp, and beneficial effect of the absence 
of mechanical management of cover crops residues with straw chopper. However, Crusciol and Soratto (2007) and Ferrari Neto et al. (2011) for growing groundnut and castor bean respectively, found no effect of cover crop on final plant density.

Table 3. Shoot dry matter production (SDM), final plant density (PD), thousand grain weight (TGW), and grain yield of crambe under different crop rotations and mechanical management of crop residues on soil surface

\begin{tabular}{|c|c|c|c|c|}
\hline Treatment & $\begin{array}{l}\text { SDM } \\
\left(\mathrm{kg} \mathrm{ha}^{-1}\right)\end{array}$ & $\begin{array}{l}\text { PD } \\
\left(\text { plant ha }{ }^{-1}\right)\end{array}$ & $\begin{array}{l}\text { TGW } \\
(\mathrm{g})\end{array}$ & $\begin{array}{l}\text { Grain yield } \\
\left(\mathrm{kg} \mathrm{ha}^{-1}\right)\end{array}$ \\
\hline \multicolumn{5}{|l|}{ Crop rotation } \\
\hline Sorghum & $981 \mathrm{~b}$ & $344,000 \mathrm{c}$ & 4.88 & $572 \mathrm{c}$ \\
\hline Pearl millet & $958 \mathrm{~b}$ & $432,000 \mathrm{~b}$ & 4.68 & $795 \mathrm{~b}$ \\
\hline Sunn hemp & $1,826 \mathrm{a}$ & $510,667 \mathrm{a}$ & 4.75 & $1,067 \mathrm{a}$ \\
\hline Brachiaria & $1,070 \mathrm{~b}$ & $445,778 \mathrm{ab}$ & 4.87 & $859 \mathrm{~b}$ \\
\hline Fallow & $880 \mathrm{~b}$ & $502,889 \mathrm{a}$ & 4.73 & $803 \mathrm{~b}$ \\
\hline $\mathrm{CV}(\%)$ & 28.4 & 9.9 & 3.7 & 13.1 \\
\hline \multicolumn{5}{|c|}{ Mechanical management of crop residues } \\
\hline Without & 1,134 & $428,444 \mathrm{~b}$ & 4.72 & 812 \\
\hline With & 1,152 & $465,778 \mathrm{a}$ & 4.84 & 826 \\
\hline $\mathrm{CV}(\%)$ & 14.7 & 11.5 & 4.8 & 13.6 \\
\hline F test & \multicolumn{4}{|c|}{ F value } \\
\hline Crop rotation $(\mathrm{CR})$ & $8.54 * *$ & $18.51^{* *}$ & $0.40 \mathrm{~ns}$ & $21.74 * *$ \\
\hline Residue management (RM) & $0.08 \mathrm{~ns}$ & $5.26^{*}$ & $1.96 \mathrm{~ns}$ & $0.17 \mathrm{~ns}$ \\
\hline Interaction (CR x RM) & $0.60 \mathrm{~ns}$ & $1.33 \mathrm{~ns}$ & $2.44 \mathrm{~ns}$ & $2.38 \mathrm{~ns}$ \\
\hline
\end{tabular}

Values represented by the different letters, for the crop rotation and management of crop residues show significant differences (Tukey test, $\mathrm{p}<0.05)$. ns: not significant. $*$ and $* *$ : statistical significance at $5 \%$ and $1 \%$, respectively, by $\mathrm{F}$ test. $1 \%$. CV: coefficient of variation.

For the thousand grains weight (TGW) was not observed effect of crop rotations and management of crop residues under no-till (Table 3 ). These results agree with those reported by Crusciol and Soratto (2007) and Ferrari Neto et al. (2011) for crops of groundnut and castor bean, respectively. The TGW of crambe observed in this study (4.68 to $4.88 \mathrm{~g}$ ) is lower than that reported for this crop by Silva et al. (2011) (6.3 to $7.7 \mathrm{~g}$ ) and Soratto et al. (2013) (6.8 to $9.3 \mathrm{~g}$ ). This result was due to temperatures below $0{ }^{\circ} \mathrm{C}$ during July (Figure 1) and occurrence of frosts that damaged the leaf area of crop in the flowering and grain filling stage.

Grain yield of crambe was affected by low temperatures, however, the grain yield in rotation the sunn hemp remained within the crop yield potential, i.e., 1,000 to $1,500 \mathrm{~kg} \mathrm{ha}^{-1}$ (Table 3), indicating the importance of residual $\mathrm{N}$ for the crambe nutrition even in adverse conditions. Broch et al. (2010) found higher grain yield of crambe in rotation to soybean $\left(1,575 \mathrm{~kg} \mathrm{ha}^{-1}\right)$ compared to maize $\left(1,002 \mathrm{~kg} \mathrm{ha}^{-1}\right)$, reporting the use of soil nitrogen by crop. Grain yield of crambe under pearl millet and brachiaria rotation and fallow treatment ranged from 795 to $859 \mathrm{~kg} \mathrm{ha}^{-1}$ (Table 3). The lowest grain yield of crambe was obtained under sorghum rotation. Rosa (2013) analyzing the structural quality of the soil in different crop rotations, found that the sunn hemp and velvet bean reduced soil bulk density compared to the fallow, however, did not affect the grain yield of crambe in succession. Evaluating different sowing times of crambe in the region western of Paraná, Viana (2013) found that grain yields ranged from 1,892; 1,350 and $530 \mathrm{~kg} \mathrm{ha}^{-1}$ for sowing in April, May and July, respectively.

Same providing higher final plant density, the use of implements for mechanical management of crop residues on the soil surface did not affect grain yield (Table 3), indicating that the mechanical management of crop residues is not necessary for growing crambe, confirming the results of Crusciol and Soratto (2007), Ferrari Neto et al. (2011) and Silva et al. (2010) in growing other species oilseeds (i.e., groundnut and castor).

The crushed of crop residues in particles approximately 50 to $70 \mathrm{~mm}$ makes these more susceptible to decomposition process, as well as high cost, low operational efficiency and greater susceptibility to soil compaction (DENARDIN; KOCHHANN, 1993). Although the mechanical management of crop residues release nutrients in the short term and provide greater seedling establishment due to less resistance to displacement 
of the drill cutting systems, the non-disintegration of the straw can promote smaller temperature changes and maintain the soil water content, improving the crop development in period of high temperatures and low rainfall. Positive results mechanical management of millet straw was discovered by Furlani Junior et al. (2013) with cotton in succession.

\section{CONCLUSIONS}

Dry matter production of forage sorghum, pearl millet and sunn hemp was higher than for grass brachiaria.

The sunn hemp crop has a higher accumulation of $\mathrm{N}$ and $\mathrm{Ca}$, whereas millet crop $\mathrm{P}$.

Dry matter and grain yield of crambe is higher in sunn hemp rotation independently of mechanical management of crop residues on the soil surface.

RESUMO: Objetivou-se com este trabalho avaliar a produção de matéria seca (MS) e o acúmulo de nutrientes por culturas de cobertura e o efeito destas, bem como do manejo mecânico da palhada nos componentes da produção e produtividade de grãos de crambe. O experimento foi conduzido em Santa Helena, Paraná, Brasil, em Latossolo Vermelho distrófico típico, em delineamento experimental de blocos ao acaso com quatro repetições em parcelas subdivididas. As parcelas foram: milheto (Pennisetum glaucum (L.) R. Brown), braquiária (Brachiaria brizantha cv. Marandu), sorgo forrageiro (Sorghum bicolor (L.) Moench), crotalária (Crotalaria juncea L.) e uma área em pousio (vegetação espontânea), e as subparcelas, pela ausência e presença do manejo mecânico de palhada $\left(\right.$ Triton $^{\circledR}$ ). A braquiária produz menor quantidade de MS e apresenta menor acúmulo de nutrientes. As demais culturas não diferem entre si na produção de MS, contudo a crotalária apresenta os maiores acúmulos de $\mathrm{N}$ e $\mathrm{Ca}$, enquanto que o milheto maior acúmulo de $\mathrm{P}$. $\mathrm{O}$ manejo mecânico da palhada não influencia os componentes de produção do crambe, porém proporciona maior densidade final de plantas. $\mathrm{O}$ crambe cultivado em sucessão a crotalária apresenta maior acúmulo de $\mathrm{MS}\left(1.826 \mathrm{~kg} \mathrm{ha}^{-1}\right) \mathrm{e}$ produtividade de grãos $\left(1.066 \mathrm{~kg} \mathrm{ha}^{-1}\right)$.

PALAVRAS-CHAVE: Crambe abyssinica. Culturas de cobertura. Manejo mecânico. Ciclagem de nutrientes.

\section{REFERÊNCIAS}

BARBOSA, C. M.; LAZARINI, E.; PICOLI, P. R. F.; FERRARI. S. Determinação da massa seca, teor de nutrientes e cobertura do solo de espécies semeadas no outono-inverno. Revista Brasileira de Ciências Agrárias, Recife, v. 6, n. 2, p. 265-272, 2011. http://dx.doi.org/10.5039/agraria.v6i2a1136

BROCH, D. L.; RANNO, S. K.; ROSCOE, R. Efeito de adubações de plantio e cobertura sobre a produtividade de crambe cv. FMS Brilhante após soja e milho. In: CONGRESSO BRASILEIRO DE MAMONA, 4; SIMPÓSIO IN TERNACIONAL DE OLEAGINOSAS ENERGÉTICAS, 1., João Pessoa, 2010. Anais...Campina Grande: Embrapa Algodão, 2010. p. 652-657.

CALONEGO, J. C.; ROSOLEM, C. A. Estabilidade de agregados do solo após manejo com rotações de culturas e escarificação. Revista Brasileira de Ciência do Solo, Viçosa, v. 32, n. 4, p. 1399-1407, 2008.

CALONEGO, J. C.; ROSOLEM, C. A. Soybean root growth and yield in rotation with cover crops under chiseling and no-till. European Journal of Agronomy, Amsterdam, v. 33, n. 3, p. 242-249, 2010. http://dx.doi.org/10.1016/j.eja.2010.06.002

CARVALHO, A. M. DE. C.; SOUZA, L. L DE, P.; GUIMARÃES JÚNIOR, R.; ALVES, P. C. A. C .; VIVALDI, L. J. Cover plants with potential use for crop-livestock integrated systems in the Cerrado region. Pesquisa Agropecuária Brasileira, Brasília, v. 46, n. 10, p. 1200-1205, 2011. http://dx.doi.org/10.1590/S0100-204X2011001000012

CERETTA, C. A.; AITA, C. O.; BRAIDA, J. A.; PAVINATO, A. O.; SALT, R. L. Fornecimento de nitrogênio por leguminosas na primavera para o milho em sucessão nos sistemas de cultivo mínimo e convencional.

Revista Brasileira de Ciência do Solo, Viçosa, v. 18, n. 2, p. 215-220, 1994.

http://dx.doi.org/10.5039/agraria.v6i4a997 
COSTA, M. S. S. M.; PIVETTA, L. A.; STEINER, F.; COSTA, L. A. M.; CASTOLDI, G.; GOBBI, F. C. Atributos químicos do solo sob plantio direto afetado por sistemas de culturas e fontes de adubação. Revista Brasileira de Ciências Agrárias, v. 6, n. 4, p. 579-587, 2011.

CRUSCIOL, C. A. C.; SORATTO, R. P. Nutrição e produtividade do amendoim em sucessão ao cultivo de plantas de cobertura no sistema plantio direto. Pesquisa Agropecuária Brasileira, Brasília, v. 42, n. 11, p. 1553-1560, 2007. http://dx.doi.org/10.1590/S0100-204X2007001100006

CRUSCIOL, C. A. C.; MATEUS, G. P.; NASCENTE, A. S.; MARTINS, P. O.; BORGHI, E.; PARIZ, C. M. An innovative crop-forage intercrop system: early cycle soybean cultivars and palisadegrass. Agronomy Journal, Madison, v. 104, n. 4, p. 1085-1095, 2012. http://dx.doi.org/10.2134/agronj2012.0002

DENARDIN, J. E.; KOCHHANN, R. A. Requisitos para implantação e a manutenção do sistema plantio direto. In: Plantio Direto no Brasil. Passo Fundo: Aldeia Norte. EMBRAPA-CNPT; FECOTRIGOFUNDACEP; FUNDAÇÃO ABC, 1993. p. 19-27.

EMPRESA BRASILEIRA DE PESQUISA AGROPECUÁRIA - EMBRAPA. Manual de análises químicas de solos, plantas e fertilizantes. 2.ed. Brasília, Informação Tecnológica, 2009. 628p.

FERRARI NETO, J.; CRUSCIOL, C. A. C, SORATTO, R. P. COSTA, C. H. M. Plantas de cobertura, manejo da palhada e produtividade da mamoneira no sistema plantio direto. Revista Ciência Agronômica, Fortaleza, v. 42, n. 4, p. 978-985, 2011. http://dx.doi.org/10.1590/S1806-66902011000400021

FERREIRA, E. P. DE B.; STONE, L. F.; PARTELLI, F. L.; DIDONET, A. D. Produtividade do feijoeiro comum influenciada por plantas de cobertura e sistemas de manejo do solo. Revista Brasileira de Engenharia Agrícola e Ambiental, Campina Grande, v. 15, n. 7, p. 695-701, 2011.

FURLANI JÚNIOR E.; NEVES, D. C.; SANTOS, M. L.; FERRARI, S. The management of cover plant residues for cotton cropped in a no-tillage system. Acta Scientiarum. Agronomy, Maringá, v. 35, n. 3, p. 371376, 2013.

MALAVOLTA, E.; VITTI, G. C.; OLIVEIRA, S. A. Avaliação do estado nutricional das plantas: princípios e aplicações. 2. ed. Piracicaba: POTAFOS, 1997. 319p.

MURAISHI, C. T.; LEAL, A. J. F.; LAZARINI, E.; RODRIGUES, L. R.; GOMES JUNIOR, F. G. G. Manejo de espécies vegetais de cobertura de solo e produtividade do milho e da soja em semeadura direta. Acta Scientiarum Agronomy, Maringá, v. 27, n. 2, p. 199-207, 2005.

NASCENTE, A. S.; CRUSCIOL, C. A. C. Cover crops and herbicide timing management on soybean yield under no-tillage system. Pesquisa Agropecuária Brasileira, Brasília, v. 47, n. 2, p. 187-192, 2012. http://dx.doi.org/10.1590/S0100-204X2012000200006

PACHECO, L. P.; LEANDRO, W. M.; MACHADO, P. L. O. A.; ASSIS, R. L.; COBUCCI, T.; MADARI, B. E.; PETTER, F. A. Produção de fitomassa e acúmulo e liberação de nutrientes por plantas de cobertura na safrinha. Pesquisa Agropecuária Brasileira, Brasília, v. 46, n. 1, p. 17-25, 2011.

http://dx.doi.org/10.1590/S0100-204X2011000100003

PERIN, A.; SANTOS, R. H. S.; URQUIAGA, S. S.; CECON, P. R.; GUERRA, J. G. M.; FREITAS, G. B. de. Sunn hemp and millet as green manure for tropical maize production. Scientia Agricola, Piracicaba, v. 63, n. 5, p. 453-459, 2006. http://dx.doi.org/10.1590/S0103-90162006000500006

PITOL, C.; BROCH, D. L.; ROSCOE, R. Tecnologia e Produção: Crambe 2010. Maracaju: Fundação MS, 2010. 60p. 
ROSA, Helton Aparecido. Potencial estruturante de espécies de cobertura em um Latossolo Argiloso e seus reflexos no rendimento de grãos e de óleo do crambe. 2012. 28 f. Dissertação (Mestrado em Energia na Agricultura) - Curso de Pós-Graduação em Energia na Agricultura, Universidade Estadual do Oeste do Paraná, Cascavel, 2013.

SILVA, A. G.; CRUSCIOL, C. A. C. SORATTON, R. P.; COSTA, C. H. M.; FERRARI, C. F. Produção de fitomassa e acúmulo de nutrientes por plantas de cobertura e cultivo da mamona em sucessão no sistema plantio direto. Ciência Rural, Santa Maria, v. 40, n. 10, p. 2092-2098, 2010. http://dx.doi.org/10.1590/S010384782010001000007

SILVA, T. R. B.; LAVAGNOLLI, R. R.; NOLLA, A. Zinc and phosphorus fertilization of crambe (Crambe abssynica Hoechst). Journal of Food Agriculture and Environment, Helsink, v. 9, n. 1, p. 132-135, 2011.

SIMIDU, H. M.; SÁ, M. E.; SOUZA, L. C. D.; ABRANTES, F. L.; SILVA, M. P.; ARF, O. Efeito do adubo verde e época de semeadura sobre a produtividade do feijão, em plantio direto em região do Cerrado. Acta Scientiarum Agronomy. Maringá, v. 32, n. 2, p. 309-315, 2010.

SORATTO, R. P. SOUZA-SCHLICK, G. D.; FERNANDES, A. M.; SOUZA, E. DE. F. Effect of fertilization at sowing on nutrition and yield of crambe in second season. Revista Brasileira de Ciência do Solo, Viçosa, v. 37, n. 3, p. 658-666, 2013.

TAVARES FILHO, J.; BARBOSA, G. M.; GUIMARÃES, M. F.; FONSECA, I. C. B. Resistência à penetração e desenvolvimento do sistema radicular do milho (Zea mays) sob diferentes sistemas de manejo em um Latossolo Roxo. Revista Brasileira de Ciência do Solo, Viçosa, v. 25, n. 3, p. 725-730, 2001.

TAVARES FILHO, J.; BARBOSA, G. M. C.; RIBON, A. A. Physical properties of dystrophic Red Latosol (Oxisol) under different agricultural uses. Revista Brasileira de Ciência do Solo, Viçosa, v. 34, n. 3, p. 925933, 2010.

TEDESCO, M. J.; GIANELLO, C.; BISSANI, C. A.; BOHNEN, H.; VOLKWEISS, S. J. Análise de solo, plantas e outros materiais. 2.ed. Porto Alegre, Universidade Federal do Rio Grande do Sul, 1995. 147p. (Boletim Técnico, 5).

VIANA, O. H. Cultivo de crambe na região oeste do Paraná. 2013. 50 f. Dissertação (Mestrado em Energia na Agricultura) - Curso de Pós-Graduação em Energia na Agricultura, Universidade Estadual do Oeste do Paraná, Cascavel, 2013. 